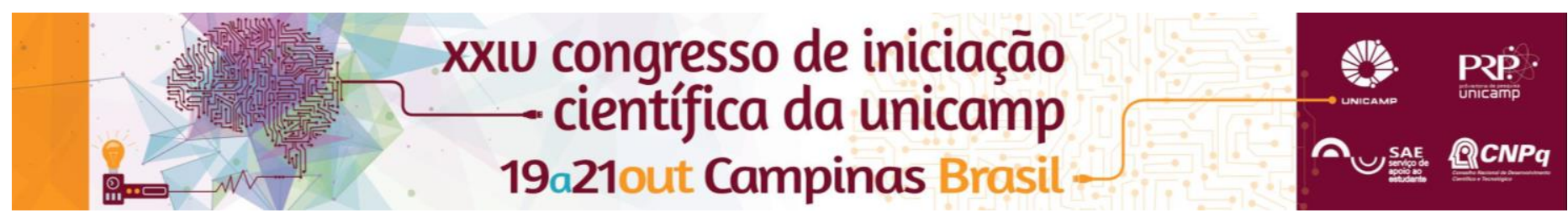

\title{
Os opostos se atraem: ciência e fantasia na literatura imperialista do século XIX, o professor Lidenbrock e sua intrigante expedição ao centro da Terra
}

\section{Aline Vieira de Carvalho; Gabriela Pratavieira de Oliveira*}

\section{Resumo}

Este trabalho tem como objetivo analisar de que forma o chamado desenvolvimento da ciência colaborou para estruturar, na literatura, o discurso imperialista. Como objeto temos uma das principais obras literárias da ficção científica do século XIX, Viagem ao Centro da Terra de Júlio Verne.

\section{Palavras-chave:}

Imperialismo, Literatura, Ciência.

\section{Introdução}

Esse projeto buscou entender como as duas ferramentas, "fantasia" e "ciência", aparentemente contraditórias para o contexto histórico atual, são empregadas por Júlio Verne para estruturar a aventura imperialista de Lidenbrock, professor de mineralogia, e seu sobrinho Áxel ao centro da Terra. Tal questionamento surgiu durante a pesquisa anterior, na qual procuramos entender se e como a fantasia e a imaginação faziam parte da construção e consolidação da ciência arqueológica. Naquele contexto, notando que o discurso científico também estava presente na obra literária, questionamos sobre o impacto de tais estudos para a literatura. Nessa nova pesquisa, procuramos entender o quanto a ciência do século XIX teve influência na escrita literária e de que modo ela é abordada nas obras para compor o discurso imperialista.

Para a análise, optamos pelo livro "Viagem ao Centro da Terra" (1864) do autor francês Júlio Verne, por ser uma das mais famosas obras iniciais da ficção científica, e de um dos maiores autores do gênero.

Para dar continuidade ao nosso trabalho, buscamos: discussões sobre a ficção científica e a fantasia na teoria literária; aprofundamentos a respeito do contexto imperialista e sua ciência; a própria análise do livro e de qual seria o papel do discurso cientifico para a narrativa; e por fim, achamos que seria interessante considerar as ilustrações de G. Dutriac, contemporâneo de Verne, responsável pelas imagens já nas primeiras edições da obra.

\section{Resultados e Discussão}

Primeiro é preciso entender a ligação de "Viagem ao Centro da Terra" com o imperialismo. De fato, tal relação não é tão óbvia quanto em outros escritos de Júlio Verne, como por exemplo, "Tribulações de um Chinês na China" ou "A Volta ao Mundo em 80 Dias", nos quais a descrição de outras culturas e populações, diferentes da do autor, demonstram uma separação entre os (qualificados como) dominadores e dominados. No entanto, embora não seja o foco da obra, devemos observar que ao descrever a Islândia - local de início da exploração - como atrasada, pobre, pacata e sem muito a oferecer além, claro, da entrada para o centro da Terra, fica evidente essa mesma hierarquização em "Viagem ao Centro da Terra".

Contudo, seu objetivo principal é a expedição. A aventura de um professor de mineralogia, colecionador, explorador e desbravador. Típica figura do século XIX: vemos o desejo por aventuras, coleções e viagens maravilhosas que o imperialismo, com sua expansão, possibilitou no imaginário europeu. Assim, fica evidente o papel crucial do contexto imperialista para a obra.

Em segundo lugar, é preciso entender o surgimento da ficção científica nesse contexto, e a relação fantasia e ciência. Com os trabalhos de Tzvetan Todorov foi possível conhecer como os gêneros ficção científica e fantasia são distintos ${ }^{1}$. Resumidamente, a história consolidada pela narrativa científica não tem o objetivo de deixar o leitor em dúvida sobre sua realidade (característica da fantasia), mas mostrar que ela é (ou será) possível de ser concretizada.

O livro de Júlio Verne nos traz esses elementos. Em cada descrição e em cada diálogo há referências e exaltações à ciência. "Quando a ciência se manifesta não há outra coisa senão calar-se"2, diz Lidenbrock, por exemplo, em uma das discussões com seu sobrinho a respeito da expedição. A obra transmite a certeza de uma viagem ao centro da Terra ser plausível.

Sobre as imagens - nove na edição em francês de 1923 - nosso objetivo é entender como elas trabalham na própria narrativa do livro (não apenas como meras ilustrações), formando em nós a imagem de lugares e personagens presentes na obra.

\section{Conclusões}

Levando em consideração a escrita da obra e as considerações teóricas feitas, podemos concluir que a obra de Júlio Verne é constituída em sua totalidade por expressões, termos, discussões e figuras ligadas à ciência, com o objetivo de dar verossimilhança à história. Percebemos como a obra, ficcional, é para que acreditemos que num futuro próximo alguém realmente consiga viajar ao centro da Terra. $O$ homem do século XIX, desbravador, seria capaz de realizá-la.

\section{Agradecimentos}

Agradeço ao CNPq por ter tornado possível essa pesquisa, e à minha orientadora Aline Vieira de Carvalho por todo o auxílio.

\footnotetext{
Todorov, Tzvetan. As Estruturas Narrativas. São Paulo: Editora Perspectiva S.A. 1970, 160

${ }^{2}$ Verne, Júlio. Viagem ao Centro da Terra. São Paulo: Artes Gráficas Bisordi S.A. Tradução: José Alberto Fomm Damásio. 1972, 84.
} 